\title{
Effects of Seminal Plasma Components on Motility and Acrosomal Integrity of Meishan Boar Spermatozoa after Cooling Treatments
}

\author{
Hiroshi HARAYAMA, Akira IMANO', \\ Masashi MIYAKE and Seishiro KATO' \\ Graduate School of Science and Technology, Kobe University, \\ Nada-ku, Kobe-shi 657-8501 \\ ${ }^{1}$ Faculty of Agriculture, Kobe University, Nada-ku, Kobe-shi 657-8501
}

(Received February 23, 1998)

\begin{abstract}
This study was conducted to determine effects of seminal plasma components on maintaining motility and acrosomal integrity in Meishan boar spermatozoa during cooling treatments. Ejaculates were collected from a Meishan boar by a manual method. Seminal plasma components were separated by dialysis and anion-exchange column chromatography. Spermatozoa resuspended in TCG solution containing seminal plasma or its components were cooled slowly to $4^{\circ} \mathrm{C}$, or rapidly to $0^{\circ} \mathrm{C}$, after which sperm motility and acrosomal integrity were examined. For those samples that were cooled slowly, the addition of seminal plasma (5-20\%, v/ v) exerted protective effects on maintaining sperm motility, but most spermatozoa were immobile at a high concentration (80\%). However, the deleterious effects on sperm motility were not detected in seminal plasma dialyzed against TCG solution. When seminal plasma components were separated into four fractions (Fractions 1-4) by anion-exchange column chromatography, the protective effects were detected in Fractions 2 and 4 . However, seminal plasma and its components hardly affected acrosomal integrity in the spermatozoa that were cooled slowly. For sperm samples that were cooled rapidly, the protective effects on acrosomal integrity as well as on sperm motility were observed in Fractions 2 and 4 . These results imply that Meishan boar seminal plasma contains both beneficial and detrimental components for maintaining sperm motility during the cooling treatments. The formers are characterized by the affinity to the anion-exchange column, i.e., molecules with isoelectric points in acidic and/or neutral ranges, and the latters are passable through the dialysis tubing, i.e., low-molecular-mass molecules.
\end{abstract}

Anim. Sci. Technol. (Jpn.) 69 (8) : 720-727, 1998

Key words : Serninal plasma, Cooling resistance, Spermatozoa, Boar

Seminal plasma is originated from epididymal plasma and accessory genital gland fluids, and contains a variety of elements ${ }^{29}$. Some components of seminal plasma have been considered to promote or inhibit sperm fertilization, such as caltrin ${ }^{9)}$, acrosome stabilizing factor ${ }^{10)}$, fertilization-associated proteins $\mathrm{s}^{20}$, fertilization promoting polypeptide $^{12)}$, BSP proteins ${ }^{31)}$, and spermadhesin ${ }^{28)}$. Indeed, different aspects have been observed in the fertilizing process between cauda epididymal and ejaculated spermatozoa ${ }^{32}$.

Boar epididymal spermatozoa are mixed with a large quantity of fluids from the accessory glands at ejaculation ${ }^{29)}$, and they become more sensitive to cooling immediately after ejaculation ${ }^{7,22)}$. Many studies on the effects of seminal plasma on motility and acrosomal integrity of spermatozoa during cooling have been made in boars of European and American 
breeds. The conclusions, however, are still subject to controvers $y^{19,23,25)}$. To our knowledge, no report is available on Meishan boars in spite of their unique reproductive characteristics ${ }^{8,13)}$. The aim of the present study is to determine effects of seminal plasma components separated by dialysis and anion-exchange column chromatography on maintaining motility and acrosomal integrity in Meishan boar spermatozoa during cooling treatments.

\section{Materials and Methods}

\section{Preparation of sperm samples and seminal plasma}

Sperm-rich fractions from ejaculates were obtained from one mature Meishan boar by a manual method using a dummy. The portion $(30 \mathrm{~m} l)$ of each sperm-rich fraction was centrifuged at $400 \mathrm{~g}$ for $10 \mathrm{~min}$ at room temperature and then the spermatozoa were separated from the supernatant. The resulting sperm pellet was resuspended in approximately $1 \mathrm{~m} l$ of TCG solution composed of $111.0 \mathrm{mM}$ Tris (hydroxymethyl) aminomethane, $34.7 \mathrm{mM}$ citric acid, and $185.0 \mathrm{mM}$ glucose ${ }^{18)}$ and the diluted aliquot was layered on a discontinuous gradient consisting of $1 \mathrm{~m} l$ of $80 \%$ Percoll (Pharmacia Biotech AB, Uppsala, Sweden) and $3 \mathrm{~m} l$ of $55 \%$ Percoll in TCG. After centrifugation at $700 \mathrm{~g}$ for $20 \mathrm{~min}$, the sperm-concentrated portion (bottom) was recovered and then washed three times with TCG solution by centrifugation at $700 \mathrm{~g}$ for $10 \mathrm{~min}$ each. After the washing treatments, the sperm pellet was resuspended in an equal volume of TCG solution.

Whole ejaculates were collected as described above and centrifuged at $14,250 \mathrm{~g}$ for $15 \mathrm{~min}$ at $4^{\circ} \mathrm{C}$ to remove spermatozoa. The obtained seminal plasma was stored at $-80^{\circ} \mathrm{C}$ before use.

\section{Cooling treatments}

The suspensions of washed spermatozoa were mixed with a four-fold volume of TCG solution containing seminal plasma and its components (see below), and used for the cooling treatments. For the slow cooling procedure, the routine procedures for liquid storage of spermatozoa were performed. Briefly, glass test tubes (volume size : $22 \mathrm{~m} l$ ) containing approximately $2 \mathrm{~m} l$ of the sperm samples were placed into about $3 l$ water $\left(20-25^{\circ} \mathrm{C}\right)$ and left overnight in a cold room $\left(4^{\circ} \mathrm{C}\right)$. The samples were cooled to $4^{\circ} \mathrm{C}$ over $4 \mathrm{~h}$ by this treatment. For the rapid cooling procedure, glass test tubes containing sperm samples were placed into wet ice $\left(0^{\circ} \mathrm{C}\right)$ and left for $20 \mathrm{~min}$.

\section{Assessment of sperm motility and ac- rosomal integrity}

Approximately $0.5 \mathrm{~m} l$ of each sperm sample after the cooling treatment was shaken at $37^{\circ} \mathrm{C}$ for $15 \mathrm{~min}$, and then the percentages of motile spermatozoa were estimated using a brightfield microscope equipped with a heated stage $\left(37^{\circ} \mathrm{C}\right)$. The remaining samples were used for the examination of acrosomal integrity ${ }^{17)}$. One drop of each sperm sample was smeared on a glass slide and air-dried on a hot plate $\left(37^{\circ} \mathrm{C}\right)$. The slide was rinsed in water, blotted, and fixed for $45 \mathrm{~min}$ in the fixative composed of $10 \%(\mathrm{v} / \mathrm{v})$ formalin in $6.8 \%$ potassium dichromate solution. After fixation, the slide was rinsed in water and stained in a phosphatebuffered solution of Giemsa stain ( $\mathrm{pH} 7.4$, Merck, Darmstadt, Germany) for $90 \mathrm{~min}$. Approximately 200 spermatozoa for each preparation were counted at random under a light microscope at $400 \times$ or $1,000 \times$ to determine the percentages of spermatozoa with a normal acrosome.

Separation of components from seminal plasma

\section{Dialysis of seminal plasma}

Dialysis tubing (Seamless Cellulose Tubing, cut-off 12,000-14,000 Da) was purchased from Wako Pure Chemical Corp. (Osaka, Japan). Seminal plasma $(30 \mathrm{~m} l)$ was dialyzed against $3 l$ TCG solution at $4^{\circ} \mathrm{C}$ twice for $24 \mathrm{~h}$ each (referred to as dialyzed seminal plasma).

\section{Anion-exchange calumn chromatography}


Seminal plasma $(200 \mathrm{~m} l)$ was treated with $80 \%$ ammonium sulfate at $4^{\circ} \mathrm{C}$. The resulting precipitate was separated by centrifugation at $14,500 \mathrm{~g}$ for $15 \mathrm{~min}$ at $4^{\circ} \mathrm{C}$. The precipitate was dissolved in $200 \mathrm{ml} 5 \mathrm{mM}$ Tris- $\mathrm{HCl}$ ( $\mathrm{pH} \mathrm{7.4)}$. The solution was dialyzed against $3 l 20 \mathrm{mM}$ Tris- $\mathrm{HCl}(\mathrm{pH} 8.0)$ for $24 \mathrm{~h}$ and then against 40 $\mathrm{mM}$ Tris- $\mathrm{HCl}(\mathrm{pH} \mathrm{9.0)}$ for $24 \mathrm{~h}$, followed by centrifugation at $14,500 \mathrm{~g}$ for $15 \mathrm{~min}$ at $4^{\circ} \mathrm{C}$ to remove insoluble constituents (referred to as precipitated seminal plasma components). When the components were used for the cooling treatment, the aliquot $(30 \mathrm{ml})$ was dialyzed against $3 l$ TCG solution at $4^{\circ} \mathrm{C}$ twice for $24 \mathrm{~h}$ each and then added to the sperm suspension. The remaining solution was applied to a DEAE-Sephacel column $(2.2 \mathrm{~cm} \times 26.5 \mathrm{~cm})$ (Pharmacia) equilibrated in $40 \mathrm{mM}$ Tris- $\mathrm{HCl}$ ( $\mathrm{pH} \mathrm{9.0)}$. Elution of components bound to the column was performed with a linear gradient obtained with $200 \mathrm{ml} 40 \mathrm{mM}$ Tris- $\mathrm{HCl}$ and $200 \mathrm{ml} 40 \mathrm{mM}$ Tris- $\mathrm{HCl}$ containing $1 \mathrm{M} \mathrm{NaCl}$ at a flow rate of $14 \mathrm{~m} l / \mathrm{h}$. The fractions of 5 or $10 \mathrm{ml}$ were collected. Prior to undergoing cooling treatments, the fractions were dialyzed against $3 l 10$ $\mathrm{mM} \mathrm{NH}_{4} \mathrm{HCO}_{3}$ buffer at $4^{\circ} \mathrm{C}$ for $24 \mathrm{~h}$, loaded on a prepacked disposable column PD-10 (Pharmacia) equilibrated in distilled water to remove low-molecular-mass (less than 1,000 Da) materials, concentrated by freeze-drying, and diluted with an equal volume of doublestrength TCG solution.

\section{Protein concentrations}

Protein concentrations in seminal plasma components were determined according to a dye-binding assay using bovine serum albumin as a standard (Bio-Rad protein assay kit, Bio-Rad Laboratories, Hercules, CA, USA).

\section{Statistical analysis}

The percentages of motile spermatozoa and of cells with a normal acrosome were subjected to analysis of variance (one-way ANOVA). When $\mathrm{F}$-test was significant, individual means were further tested by Tukey's multiple range test ${ }^{24)}$.

\section{Results}

Figure 1 shows effects of seminal plasma on sperm motility after the slow cooling treatment. The percentages of motile spermatozoa were increased by the addition of the intact seminal plasma in a dose-dependent manner between 0 and $20 \%(\mathrm{v} / \mathrm{v})$, but decreased markedly at $80 \%$. However, such adverse effect was not observed in dialyzed seminal plasma.

The precipitated seminal plasma component solution was as effective as the dialyzed seminal plasma in the maintenance of sperm motility during the slow cooling treatment (data not shown). The typical pattern of fractionation of precipitated seminal plasma components by the DEAE-Sephacel column
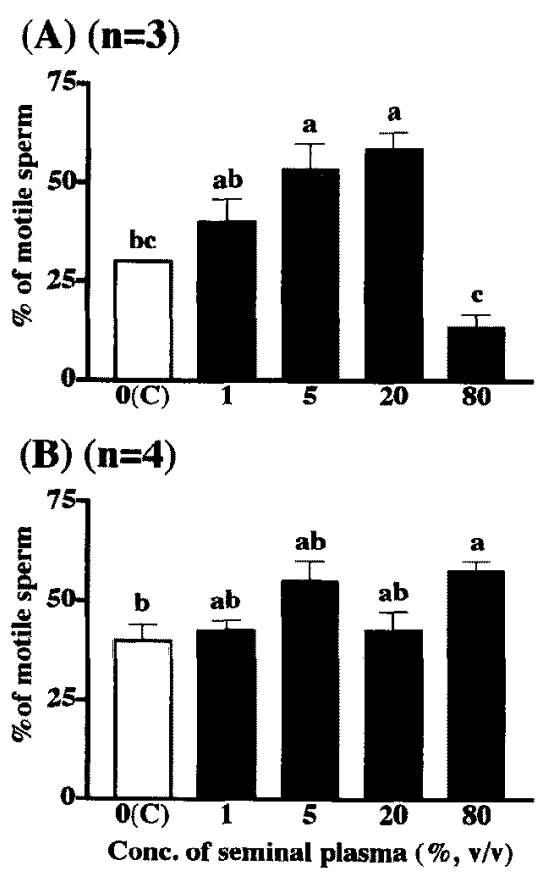

Fig. 1. Effects of intact (A) and dialyzed seminal plasma (B) on motility of ejaculated boar spermatozoa after the slow cooling treatment. Values are means $\pm S E M$ of the data which were obtained in the sperm samples shaken at $37^{\circ} \mathrm{C}$ for 15 min after the cooling treatment. Values with different superscripts differ significantly, $P<0.05$. 

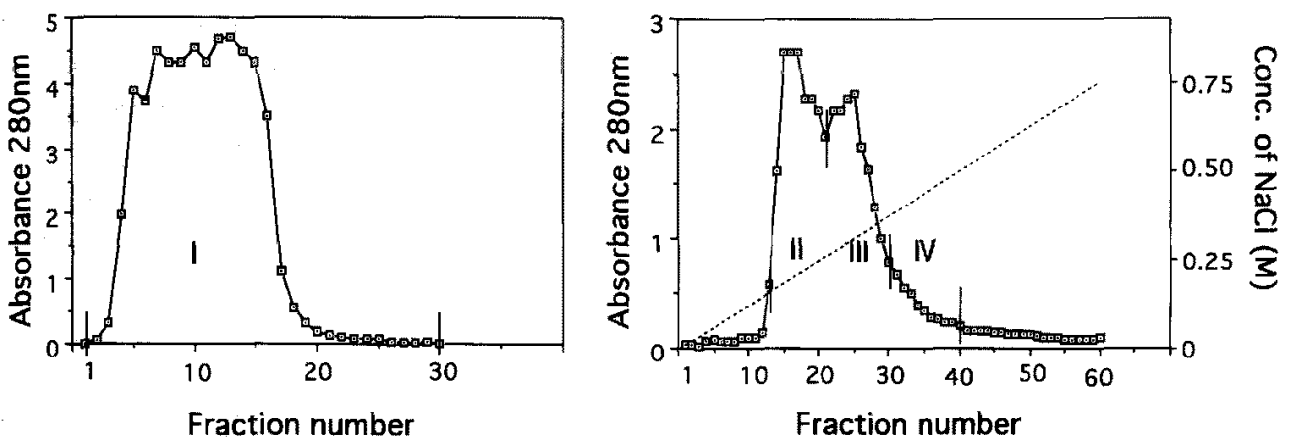

Fig. 2. Chromatography of boar seminal plasma components on DEAE-Sephacel column. Fractions of $10 \mathrm{~m} l$ (unbound portion : left figure) and of $5 \mathrm{ml}$ (bound portion : right figure) were collected at a flow rate of $14 \mathrm{ml} / \mathrm{h}$. The absorbance was monitored at $280 \mathrm{~nm}$. The column $(2.2$ $\mathrm{cm} \times 26.5 \mathrm{~cm}$ ) was equilibrated in $40 \mathrm{mM}$ Tris- $\mathrm{HCl}(\mathrm{pH} 9.0)$. Bound components were eluted with a linear gradient obtained with $200 \mathrm{ml} 40 \mathrm{mM}$ Tris- $\mathrm{HCl}(\mathrm{pH} 9.0)$ and $200 \mathrm{ml} 40 \mathrm{mM}$ Tris- $\mathrm{HCl}$ containing $1 \mathrm{M} \mathrm{NaCl}(\mathrm{pH} 9.0)$.

Table 1. Effects of seminal plasma components separated by anion-exchange column chromatography (Fractions 1-4) on motility of ejaculated boar spermatozoa after the slow cooling treatment $(n=5)$

\begin{tabular}{|c|c|c|c|c|c|}
\hline $\begin{array}{l}\text { Fractions } \\
(\mu \mathrm{g} \text { protein } / \mathrm{m} l)^{a}\end{array}$ & $\begin{array}{c}\text { Control } \\
(0)\end{array}$ & $\begin{array}{c}1 \\
(500)\end{array}$ & $\begin{array}{c}2 \\
(500)\end{array}$ & $\begin{array}{c}3 \\
(500)\end{array}$ & $\begin{array}{c}4 \\
(352)\end{array}$ \\
\hline$\%$ of motile sperm & $38 \pm 5^{e}$ & $48 \pm 5^{\text {de }}$ & $65 \pm 3^{\circ}$ & $48 \pm 3^{\text {de }}$ & $58 \pm 3^{\text {ca }}$ \\
\hline
\end{tabular}

Final concentration of protein in sperm suspension.

- The percentages of motile sperm were obtained in the sperm samples shaken at $37^{\circ} \mathrm{C}$ for $15 \mathrm{~min}$ after the cooling treatment.

de Values within the same line with different superscripts differ significantly, $\mathrm{P}<0.05$.

Values are means \pm SEM.

chromatography is illustrated in Fig. 2. The effects of Fractions 1-4 on sperm motility after the slow cooling treatment are shown in Table 1 and Fig. 3. Significantly higher percentages of motile spermatozoa were obtained by the addition of the Fractions $2(500 \mu \mathrm{g}$ protein $/ \mathrm{m} l$ at the final concentration in sperm suspension) and 4 ( $352 \mu \mathrm{g}$ protein $/ \mathrm{m} l$ ), compared to control. The increases in the percentages were dependent on the concentrations of these fractions. Similar effects of the Fractions 2 and 4 on sperm motility were observed in the samples after the rapid cooling treatment (Table 2). Moreover, the percentages of spermatozoa with a normal acrosome after the rapid cooling treatment were significantly higher in the sperm samples containing these fractions (Table 2).

\section{Discussion}

The effects of seminal plasma components on the motility of ejaculated spermatozoa have been extensively studied. Low-molecularmass basic components have deleterious effects on motility of spermatozoa from boars ${ }^{30}$ and bulls, ${ }^{1,2}$. Also, a $50 \mathrm{kDa}$ boar seminal vesicle basic protein composed of 14,16 , and $18 \mathrm{kDa}$ subunits reduces sperm motility by inhibiting motility-dynein ATPase ${ }^{15,16)}$. By contrast, a supplement of ram seminal plasma $(10 \%, v / v)$ 


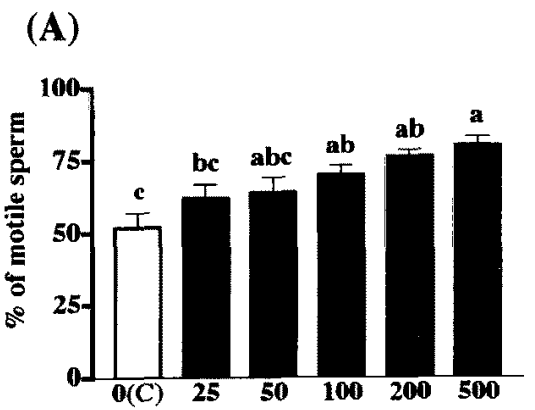

(B)

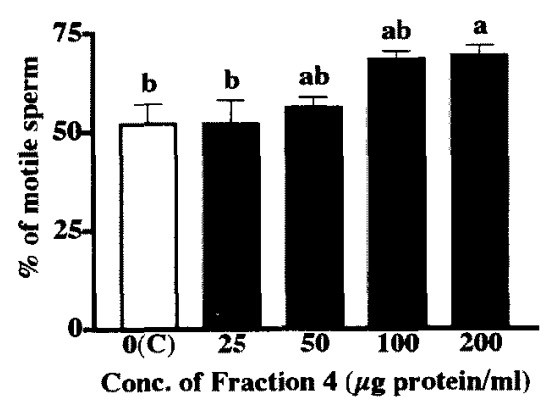

Fig. 3. Effects of increasing concentrations of Fractions 2 and 4 of seminal plasma components separated by anion-exchange column chromatography on motility of ejaculated boar spermatozoa after the slow cooling treatment $(n=5)$. Values are means \pm SEM of the data which were obtained in the sperm samples shaken at $37^{\circ} \mathrm{C}$ for 15 min after the cooling treatment. Values with different superscripts differ significantly, $P<0,05$. or of the $5-10 \mathrm{kDa}$ fractions from it to a saline medium produces protective effects on the survival of spermatozoa incubated in vitro ${ }^{3)}$. Moreover, bull seminal plasma contains $<0.5$ $\mathrm{kDa}$ motility-stimulating factors for spermatozoa inactivated by washing with Ficoll ${ }^{5)}$. These observations indicate that seminal plasma contains both detrimental and beneficial components for motility of ejaculated spermatozoa. On the other hand, detrimental components of seminal plasma for the spermatozoa cooled or stored below $15^{\circ} \mathrm{C}$ have been characterized. The reduction of motility in boar spermatozoa coincident with cooling seems to be associated with basic proteins from seminal vesicles "haemagglutinin" ${ }^{26)}$. Moore et al. ${ }^{227}$ have reported that the addition of seminal vesicle basic proteins causes damage in plasma membrane integrity and the releasing of enzymes at the sperm head and mid-piece when boar spermatozoa were cooled. Possibly these events may be due to the increased permeability of the membrane $e^{14,277}$. However, Berger and $\mathrm{Clegg}^{7)}$ have indicated seminal vesicle secretions are not important in sensitizing the acrosomal membrane to the rapid cooling treatment. By contrast, only limited data are available regarding the characterization of components enhancing sperm cooling

Table 2. Effects of seminal plasma components separated by anion-exchange column chromatography (Fractions 1-4) on motility and acrosomal integrity of ejaculated boar spermatozoa after the rapid cooling treatment $(n=5)$

\begin{tabular}{|c|c|c|c|c|c|}
\hline $\begin{array}{l}\text { Fractions } \\
(\mu \mathrm{g} \text { protein } / \mathrm{m} l)^{\mathrm{a}}\end{array}$ & $\begin{array}{c}\text { Control } \\
(0)\end{array}$ & $(500)$ & $\begin{array}{c}2 \\
(500)\end{array}$ & $\begin{array}{c}3 \\
(500)\end{array}$ & $\begin{array}{c}4 \\
(352)\end{array}$ \\
\hline$\%$ of motile sperm & $19 \pm 5^{d}$ & $32 \pm 4^{\mathrm{cd}}$ & $40 \pm 5^{c}$ & $36 \pm 7^{\text {cd }}$ & $44 \pm 4^{c}$ \\
\hline $\begin{array}{l}\% \text { of sperm with } \\
\text { normal acrosome }\end{array}$ & $4 \pm 0^{e}$ & $6 \pm 1^{\text {de }}$ & $10 \pm 1^{\text {cd }}$ & $6 \pm 2^{\text {cde }}$ & $12 \pm 2^{c}$ \\
\hline
\end{tabular}

- Final concentration of protein in sperm suspension.

The percentages of motile sperm were obtained in the sperm samples shaken at $37{ }^{\circ} \mathrm{C}$ for $15 \mathrm{~min}$ after the cooling treatment. The percentages of sperm with a normal acrosome were assessed by the observation of sperm preparations stained with a phosphate-buffered solution of Giemsa stain.

cde Values within the same line with different superscripts differ significantly, $\mathrm{P}<0.05$.

Values are means \pm SEM. 
resistance, although the presence of them has been assumed ${ }^{4,11,19,25)}$.

In the present study, the addition of Meishan boar seminal plasma at a concentration of $80 \%$ $(\mathrm{v} / \mathrm{v})$ adversely affected sperm motility after the slow cooling treatment (Fig. 1), although more than $70 \%$ of spermatozoa were motile immediately before the cooling treatment (data not shown). However, dialysis against TCG solution (cut-off, 12,000-14,000 Da) abolished the deleterious effects (Fig. 1). These findings suggest that boar seminal plasma contains damaging factors for sperm motility during the slow cooling treatment. Moreover, the factors can be removed from seminal plasma by the dialysis. This is supported by the previous results obtained with boars of European and American breeds ${ }^{(6)}$ that motility of boar spermatozoa was maintained at the high level for 7 days by dialyzing semen in cellulose tubing at $15^{\circ} \mathrm{C}$. However, it remains to be determined the factors which exert deleterious effects on cooling resistance or motility system in spermatozoa.

Our results revealed that the addition of seminal plasma (5-20\%) to TCG solution increased. the percentages of motile spermatozoa after the slow cooling treatment (Fig, 1). This is in agreement with the previous results obtained with Landrace boar spermatozoa stored at $4^{\circ} \mathrm{C}$ for 5 days in TCG solution containing egg yolk ${ }^{19)}$, although aggregation of egg yolk occurred by the seminal plasma components ${ }^{21)}$. When Fractions 2 and 4 were added to sperm samples, the percentages of motile spermatozoa after the slow cooling treatment increased in a dose-dependent manner (Table 1 and Fig. 3). Although the addition of these fractions had little influence on the percentages of motile spermatozoa immediately before cooling treatments (data not shown), they had protective effects on maintaining the motility of spermatozoa during the rapid cooling treatment (Table 2). These fractions also exerted protective effects on the acrosomal integrity of spermatozoa cooled rapidly (Table 2). These findings imply that Meishan boar seminal plasma contains components enhancing cooling resistance in spermatozoa.

Our data suggest that Meishan boar seminal plasma contains both beneficial and detrimental components for maintaining sperm motility during the cooling treatment. The formers are characterized by the affinity to the anionexchange column, i.e., molecules with isoelectric points in acidic and/or neutral ranges, and the latters are passable through the dialysis tubing, i.e., low-molecular-mass molecules. It could be also suggested that protective effects of seminal plasma components should be taken into consideration when developing protocols for liquid storage of Meishan boar spermatozoa. However, these suggestions remain to be confirmed for spermatozoa ejaculated from boars of other breeds.

\section{Acknowledgments}

The authors thank T. Nakamura for technical assistance. This study was supported in part by a Grant from Ito Kinen Foundation to H.H. and by a Grant-in-Aid from the Ministry of Education, Science, Sports and Culture of Japan to H.H. (No. 09760256).

\section{References}

1) Al-Somai N, Vishwanath R, Molan PC, Shannon P. Anionic and cationic components from protein aggregates in bovine seminal plasma and their effects on sperm motility. Mol. Reprod. Dev., 39 : 328-336. 1994.

2) Al-Somai N, Vishwanath R, Shannon P, Molan PC. Low molecular weight components in bovine semen diffusate and their effects on motility of bull sperm. Reprod. Fertil. Dev., 6 : 165-171. 1994.

3) Ashworth PJC, Harrison RAP, Miller NGA, Plummer JM, Watson PF. Survival of ram spermatozoa at high dilution: protective effect of simple constituents of culture media as compared with seminal plasma. Reprod, Fertil. Dev., 6 : 173-180. 1994.

4) Aurich JE, Kühne A, Hoppe H, Aurich C. Seminal plasma affects membrane integrity and 
motility of equine spermatozoa after cryopreservation. Theriogenology, 46:791797. 1996.

5) Baas JW, Molan PC, Shannon P. Factors in seminal plasma of bulls that affect the viability and motility of spermatozoa. J. Reprod. Fertil., $68: 275-280.1983$.

6) Bamba K, Sone M, Takeda K. Studies on the storage of undiluted boar semen by means of dialysis : effects of various dialysis fluids on the motility and acrosome morphology of spermatozoa. Jpn. J. Zootech. Sci., $50: 740-746$. 1979.

7) Berger $T$, Clegg ED. Effect of male accessory gland secretions on sensitivity of porcine sperm acrosomes to cold shock, initiation of motility and loss of cytoplasmic droplets. J. Anim. Sci., $60:$ 1295-1302. 1985.

8) Bidanel JP, Legault C. Experimental and prospective aspects of the utilisation of prolific Chinese pig breeds in Europe. Proc. 37th Meeting of European Assoc. for Anim. Prod. (Budapest), $1:$ 104-105. 1986.

9) Coronel CE, Winnica DE, Novella ML, Lardy HA. Purification, structure, and characterization of caltrin proteins from seminal vesicle of the rat and mouse. J. Biol. Chem., 267 : 2090920915. 1992.

10) Eng LA, Oliphant G. Rabbit sperm reversible decapacitation by membrane stabilization with a highly purified glycoprotein from seminal plasma. Biol. Reprod., 19 : 1083-1094. 1978.

11) Graham JK. Effect of seminal plasma on the motility of epididymal and ejaculated spermatozoa of the ram and bull during the cryopreservation process. Theriogenology, 41 : 1151-1162. 1994.

12) Green CM, Cockle SM, Watson PF, Fraser LR. A possible mechanism of action for fertilization promoting peptide, a TRH-related tripeptide that promotes capacitation and fertilizing ability in mammalian spermatozoa. Mol. Reprod. Dev., 45 : 244-252. 1996.

13) Harayama H, Nanjo I, Kanda S, Kato S. Testicular development in Chinese Meishan boars. Theriogenology, $36: 637-643.1991$.

14) Hibbitt KG, Benians $M$. Some effects in vivo of the teat canal and effects in vitro of cationic proteins on Staphylococci. J. Gen. microbiol., $68: 123-128.1971$.

15) I wamoto $T$, Tanaka $H$, Osada $T$, Shinagawa $T$, Osamura Y, Gagnon C. Origin of a sperm motility inhibitor from boar seminal plasma.
Mol. Reprod. Dev., 36 : 475-481. 1993.

16) Iwamoto $T$, Tsang A, Luterman $M$, Dickson $J$, de Lamirande E, Okuno M, Mohri H, Gagñon C. Purification and characterization of a sperm motility-dynein ATPase inhibitor from boar seminal plasma. Mol. Reprod. Dev., 31 : 55-62. 1992.

17) Kato $S$, Inoue $Y$, Iritani A, Nishikawa $Y$. Individual differences in freezability of boar spermatozoa. Jpn. J. Frozen Semen Res. Soc., $44: 7-10.1974$.

18) Kato S, Iritani A, Nishikawa Y. Study on composition of diluent for frozen storage of boar semen. Jpn. J. Zootech. Sci., 45 : 58 Abstr. 1974.

19) Kato $S$, Yasui $T$, Miyano $T$, Nanjo I, Kanda S. Effect of seminal plasma on motility and acrosome morphology of boar spermatozoa stored at $4{ }^{\circ} \mathrm{C}$. Sci. Rept. Fac. Agr. Kobe Univ., 19:5762. 1990.

20) Killian GJ, Chapman DA, Rogowski LA. Fertility-associated proteins in Holstein bull seminal plasma. Biol. Reprod., 49 : 1202-1207. 1993.

21) Masuda H, Soejima A, Waide $Y$. Agglutination phenomena of various kinds of dilutors with boar semen and the origin of agglutinating factors in the semen. Jpn. J. Anim. Reprod., 23: 121-125. 1977.

22) Moore HDM, Hall GA, Hibbitt KG. Seminal plasma proteins and the reaction of spermatozoa from intact boars and from boars without seminal vesicles to cooling. J. Reprod. Fertil., $47: 39-45.1976$.

23) Moore HDM, Hibbitt KG. Fertility of boar spermatozoa after freezing in the absence of seminal vesicular proteins. J. Reprod. Fertil., $50: 349-352.1977$.

24) Motulsky H. Intuitive Biostatistics. 255-262. Oxford University Press. New York. 1995.

25) Pursel VG, Johnson LA, Schulman LL. Effect of dilution, seminal plasma and incubation period on cold shock susceptibility of boar spermatozoa. J. Anim. Sci, 37 : 528-531. 1973.

26) Roberts TK, Boursnell JC, Brown AD. The role of zinc in promoting the opalescence and cold precipitation of boar seminal plasma. II. Relationships of a zinc-precipitable protein with the haemagglutinin. J. Reprod. Fertil., 37 : 373386. 1974.

27) Ryser HJ-P, Hancock R. Histones and basic polyamino acids stimulate the uptake of albumin by tumor cells in culture. Science, 150 : 501-503. 1965.

28) Sanz L, Calvete JJ, Mann K, Gabius H-J, 


\title{
Sperm Cooling Resistance and Seminal Plasma
}

Töpfer-Petersen E. Isolation and biochemical characterization of heparin-binding proteins from boar seminal plasma: a dual role for spermadhesins in fertilization. Mol. Reprod. Dev., 35 : 37-43. 1993.

29) Setchell BP, Brooks DE. Anatomy, Vasculature, innervation, and fluids of the male reproductive tract. In : The Physiology of Reproduction. (Knobil E, Neill J eds.) 753-836. Raven Press, Ltd. New York. 1988.

30) Strzezek J, Kordan W, Kostyra H, Zaborniak A. Purification and partial characterization of a
5,700 Da sperm motility inhibiting factor from seminal plasma of boar. Anim. Reprod. Sci., $29: 35-52.1992$.

31) Thérien I, Bleau G, Manjunath P. Phosphatidylcholine-binding proteins of bovine seminal plasma modulate capacitation of spermatozoa by heparin. Biol. Reprod., 52 : 1372-1379. 1995 .

32) Yanagimachi R. Mammalian fertilization. In : The Physiology of Reproduction. (Knobil E, Neill J eds.) 2nd ed. 189-317. Raven Press, Ltd. New York. 1994.

\section{冷却処理後の梅山豚射出精子の運動性および先体の形態に 及ぼす精漿成分の影響}

\author{
原山 洋・今野 彰 ${ }^{1} \cdot$ 三宅正史・加藤征史郎 ${ }^{1}$ \\ 神戸大学人学院自然科学研究科, 神戸市灘区 657-8501 \\ ${ }^{1}$ 神戸大学農学部, 神戸市灘区 $657-8501$
}

冷却処理中の梅山豚精子の運動性および先体の正常性の維持に及ばす精獎成分の影響について検討し た．精漿成分は透析および陰イオン交換カラムクロマトグラフィーにより分晟した，ついで，洗浄した 射出精子を浮遊させた TCG 液に精漿成分を添加した後， $4^{\circ} \mathrm{C}$ まで縟慢に，または $0^{\circ} \mathrm{C}$ まで急速に泠却 し，冷却処理後の精子の運動性扔よび先体の正常性を観察した，綏慢冷却される綪子浮遊液に5 20\%

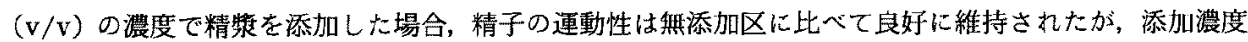
を $80 \%$ にすると大部分の精子が運動性を失った．しかし，透析処理後の精漿では添加浱度 $80 \%$ 区に扝 いても精子の運動性は良好に維持された。陰イオン交换カラムクロマトグラフィーにより精獎成分を 4 分画（分画 1 4）に分離した場合, 緩慢冷却後の精子の運動性維持には分画 2 および 4 が好適に作用し た。しかし，これらの精墏成分は䌅慢冷却された精子での先体の正常性維持にはほとんど影響しなかっ た。他方，急速冷却される精子浮遊液に分画 2 および 4 の精墏成分を添加した場合には，精子の運動性 および先体の正常性の両方が無添加区上りも良好に維持された，以上の結果上り，梅山豚の精浆には冷 却処理中の精子の運動性の維持に有害な成分だけでなく好遮な成分も含まれ、これらの成分はそれぞれ 低分子マス成分，および酸性域または中性域に等電点をあつ成分と推定される。

日畜会報, $69(8): 720-727,1998$ 